\title{
Girit Adası ve Rodos Baseni'nin (Doğu Akdeniz) Dengeleme Mekanizmasının Girişim (Admittance) Fonksiyonu ile Araştırılması
}

\author{
Analyzing the Compensation Mechanism of Crete Island and \\ Rhodos Basin (Eastern Mediterranean Sea) with \\ Admittance Function

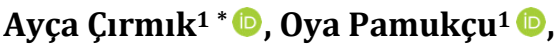

\begin{abstract}
${ }^{1}$ Dokuz Eylül Üniversitesi, Mühendislik Fakültesi, Jeofizik mühendisliği Bölümü, İzmir, TÜRKIYE Sorumlu Yazar / Corresponding Author*: ayca.cirmik@deu.edu.tr

Atıf sekli/How to cite: CIRMIK, A., PAMUKÇU, O.(2020). Girit Adası ve Rodos Baseni'nin (Doğu Akdeniz) Dengeleme Mekanizmasının Girişim (Admittance) Fonksiyonu ile Araștırılması. DEUFMD 22(65), 541-559.
\end{abstract}

\section{$\ddot{\mathbf{O z}}$}

Kabuğun ve üst mantonun, topoğrafik yükleri gravitasyonel olarak nasıl dengelediği tektonik açıdan önemli bir kavramdır. Bir bölgedeki yüklerin dengelenme durumu, o bölgeye ait topoğrafya ve gravite verilerinin irdelenmesi ile belirlenebilmektedir. Tektonik olarak oldukça karmaşı olan Doğu Akdeniz bölgesinin dengelenme mekanizması, girișim (Admittance) fonksiyonun kullanılmasıyla literatür genelinde ilk olarak bu çalışma kapsamında irdelenmiştir. Bu kapsamda, farklı topoğrafik/batimetrik, gravitasyonel değerlere ve tektonik özelliklere sahip Doğu Akdeniz bölgesi, Girit Adası ve Rodos baseni olmak üzere iki ayrı bölgeye ayrılarak incelenmiş, gravite ve topoğrafya verileri arasındaki girişim (admittance) uyumundan yararlanılarak bu bölgelerin efektif elastik kalınlık değerleri ve ayrıca düz-ters çözüm teknikleri ile kabuk-manto ara yüzeyine ait bükülme derinlikleri elde edilmiştir. Sonuç olarak, Doğu Akdeniz'de yer alan bu iki bölgenin izostatik modellerinin Airy modeline uymadığı, Girit Adası ve çevresi için efektif elastik kalınlık değerinin ortalama 6 km olduğu, Rodos baseni ve çevresi için efektif elastik kalınlık değerinin ortalama 8 km olduğu saptanmıștır. En uygun efektif elastik kalınlık değerine karşılık gelen kabuk-manto ara yüzeylerine ait ortalama bükülme derinliklerinin Girit Adası ve çevresinde yaklaşık 19-29 km, Rodos Baseni ve çevresinde ise 20-32 km arasında değiştiği saptanmıştır.

Anahtar Kelimeler: Doğu Akdeniz, Girit, Rodos baseni, efektif elastik kalınlık, ters çözüm, girişim (admittance) analizi

\section{Abstract}

It is a tectonically important concept how the crust and the upper mantle gravitationally balancing the topographic loads. Balancing the loads in a region can be determined by examining the topographic and gravity data. In this study, the balancing mechanism of Eastern Mediterranean region, which is quite tectonically complex, was determined by using Admittance function as the first time in the literature. In this context, Eastern Mediterranean region, which has different topographic/bathymetric, gravity values and tectonic features, was divided into two regions as Crete Island and Rhodos basin. The effective elastic thickness values of these regions were obtained by using the coherency of admittance between gravity and topography values and average flexure depths of the crustal-mantle interfaces were calculated by forward-inverse solutions. As the result, it is determined that the isostatic models of Eastern Mediterranean regions do not fit with the Airy model 
and the effective elastic thickness values of Crete Island-its surroundings and Rhodos basin-its surroundings are approximately $6 \mathrm{~km}$ and $8 \mathrm{~km}$, respectively. The average flexure depths of the crustal-mantle interfaces related to the optimal effective elastic thickness value of Crete Island and Rhodos basin are approximately $19-29 \mathrm{~km}$ and $20-32 \mathrm{~km}$, respectively.

Key Words: Eastern Mediterranean, Crete, Rhodos basin, effective elastic thickness, forward modelling, admittance analysis.

\section{Giriș}

Doğu Akdeniz bölgesi, Afrika ile Avrasya levhalarının çarpışmaları ile Arap, Anadolu ve Ege levhalarının yer değiştirmeleriyle şekillenmektedir. Bu tektonik hareketin, Tetis Okyanusu'nun kapanışı ile başladığı bilinmektedir [1-8]. Bir başka deyişle, Doğu Akdeniz yakınsayan kıta hareketlerini içeren okyanusal ve kitasal kabuğun birlikte yeraldığı karmaşık bir bölgedir [9, 10]. Doğu Akdeniz bölgesindeki en önemli tektonik elemanlarından biri Girit Adasının güneyinde yer alan Helenik yaydır (Şekil 1). Helenik yay; Akdeniz ile Ege Denizi'ni birbirinden ayırmakta ve batimetrik açıdan değişken derinliklere sahip olmakla birlikte bölgenin en derin kısmını içermektedir (yaklaşık 3.500 m). Doğu Akdeniz'deki en derin yapılardan bir diğeri ise Rodos Adasının doğusunda yeralan Rodos basenidir ve yaklaşık derinliği 4.000 m'dir [11]. Rodos baseni Miyosen zamanında bölgedeki yatay ve düşey yönlü hareketler sonucunda oluşmuştur [12].

Girit Adası'nın doğu ve batı kısımlarının fiziksel özellikleri önemli ölçüde farklılıklara sahiptir [13]. Bu bölgede sismik ve gravite yöntemleri kullanılarak yapılan çalışmada [14] kabuk kalınlığı Girit Adası'nın orta kısımlarında 32-34 $\mathrm{km}$ olarak saptanmıștır. Sismik hızların kullanıldığı çalışmada [13] ise ortalama kalınlık yaklaşık $30 \mathrm{~km}$ olarak bulunmuştur [15].

Topoğrafik/batimetrik, jeolojik ve jeofiziksel açıdan farklılıklar içeren Doğu Akdeniz bölgesi bu çalışmada, Girit Adası çevresi (I. Bölge) ve Rodos Baseni çevresi (II. Bölge) bölgeleri olmak üzere iki ayrı çalıșma alanı olarak incelenmiștir.

Bir bölgenin tektonik özelliklerini irdelemek amaciyla doğrusal transfer fonsiyonlarından biri olan girişim fonksiyonunun kullanılmasıyla bölgeye ait litosferik bükülme modeli çalıșmaları yapılmaktadır. Litosferik bükülme modelinde kullanılan plakaya bir yük bindirilmekte ve bindirilen yüke karşı plakanın verdiği yanıt, bir diğer deyişle bükülme rijiditesi, plakanın efektif elastik kalınlığı olarak karakterize edilmektedir [16]. Bu modelde topoğrafik yükler, bükülme ve kabuksal kalınlı ile dengelenmektedir. Litosferik bükülme modeli ile ilişsili olan izostatik dengelemeyi tanımlamak için yeraltı kütlelerinin neden olduğu yerçekimi anomalileri ile topoğrafya arasındaki ilişki kullanılmaktadır. Bir çok çalışmada [örn., 17-28] bu ilişkiden yararlanılarak doğrusal transfer teknikleri ile efektif elastik kalınlık kestirimleri yapılmıştır.

$\mathrm{Bu}$ çalışmada, girişim fonksiyonunun kullanılmasıyla oldukça karmașı tektonik özelliği sahip olan Doğu Akdeniz bölgesinin litosferik bükülme modeline ait efektif elastik kalınlık $\left(\mathrm{T}_{\mathrm{e}}\right)$ parametresi saptanmıștır. $\mathrm{Bu}$ kapsamda Bouguer gravite ve topoğrafya verilerinin birlikte kullanılmasıyla bölgeye ait girişim fonksiyonları hesaplanmıştır. Sonraki aşamada, Lithoflex 1.2 yazılımının [29, 30] kullanılmasıyla gravite ters çözümünden kabukmanto ara yüzeyi kestirimi yapılmıștır. Ardından bölgeye ait yük modeli kullanılarak düz çözüm yöntemi ile yine kabuk-manto ara yüzeyi saptanmıştır. Son olarak, bu iki uygulamadan elde edilen ara yüzey değerleri karşılaştırılmıştır.

Yapılan çalıșmaların sonucunda Doğu Akdeniz bölgesinde bulunan Girit Adası, Rodos baseni ve çevrelerini kapsayan her iki bölgenin de izostatik modellerinin Airy modeline uymadığ saptanmıştır. Efektif elastik kalınlık değerleri Girit ve çevresi için ortalama $6 \mathrm{~km}$, Rodos baseni ve çevresi için ortalama $8 \mathrm{~km}$ olarak elde edilmiștir. Ayrıca, en uygun efektif elastik kalınlık değeri ile uyumlu kabuk-manto ara yüzeylerine ait ortalama bükülme derinlik değerlerinin Girit ve çevresi için 19-29 km; Rodos Baseni ve çevresi için ise 20-32 km arasında değiştiği belirlenmiştir. 


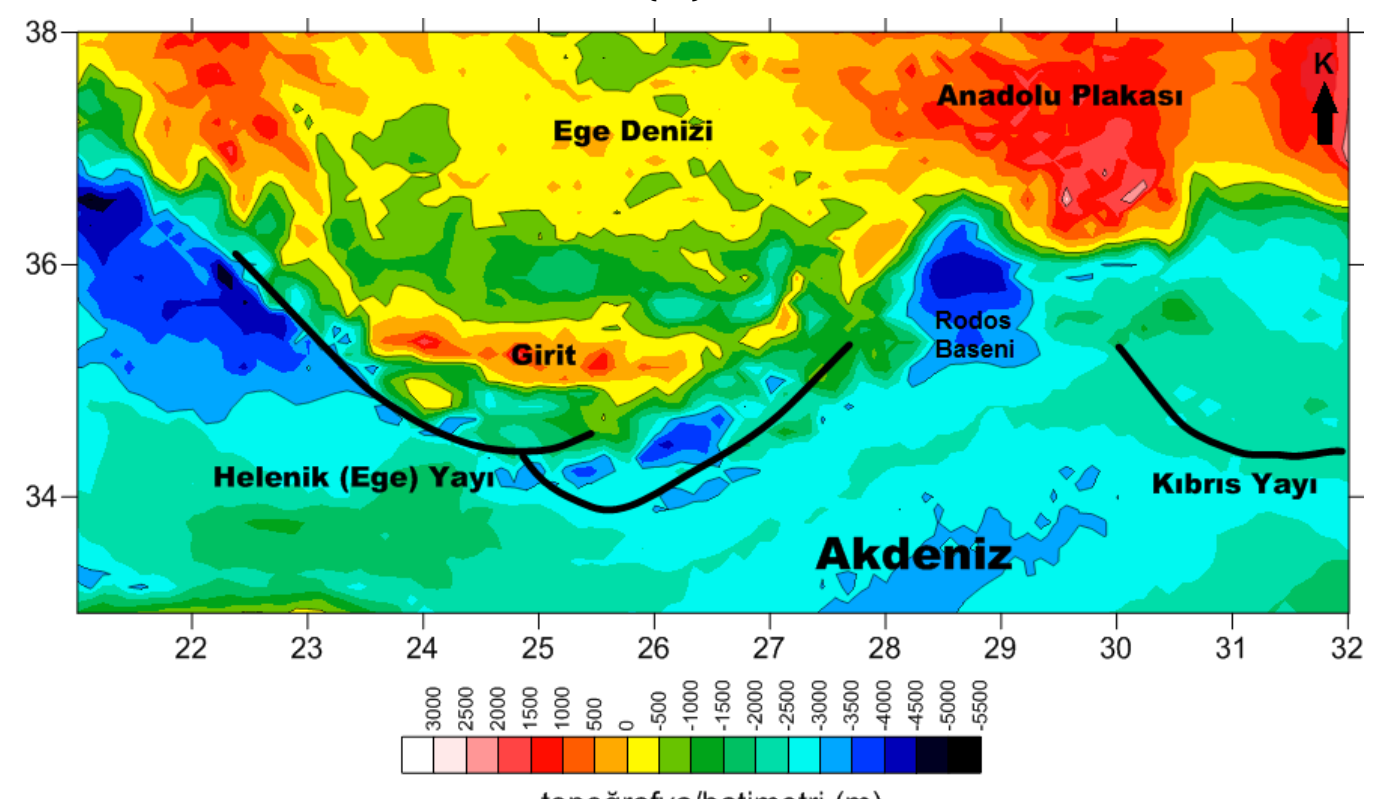

topoğrafya/batimetri $(\mathrm{m})$

Şekil 1. Doğu Akdeniz ve çevresinin topoğrafya/batimetri ve temel tektonik haritası [31]. Topoğrafya/batimetri verileri [32]'den elde edilmiştir.

\section{Yöntem}

2.1 Elastik kalınlık, bükülme rijiditesi ve elastik plaka teorisi

Rejyonal izostazi modelinde litosfer üzerine yüklenen yükler litosferin kalınlığına göre litosfer tarafından dengelenmektedir. Ağırlığı belli bir topoğrafik yük, ince bir litosfere yüklendiğinde litosferdeki bükülme fazla iken aynı yükün daha kalın bir litosferde yarattığı bükülme daha az olmaktadır. Güçlü ve zayıf olmak üzere farklı litosferlerik ortamların üzerine etkiyen aynı büyüklükteki yüklere karşı litosferlerdeki dengeleme mekanizmasını daha basit bir şekilde ifade edebilmek için yüzeydeki lineer yüklerin plaka üzerindeki etkileri modellenmiștir [33]. Bükülme modeli, kabuk ve mantonun yüklemeye karşı yanıtını, ne kadar eğildiklerini ve hangi koşullar altında kırıldıklarını açıklamaktadır. Bu yaklaşımları, lokal dengeleme özellikleri gösteren Airy ve Pratt modellerinde uygulamak mümkün olmamaktadır. Plaka teorisi kapsamında geliștirilen bükülme veya elastik plaka modelleri litosferik yükün ortadan kalkması durumunda kabuk ve üst mantonun bir elastik malzeme gibi hareket ettiğini kabul etmektedir. Eğer bu yükler büyük ise yükü dengelemeye çalıșan kayaçlar aynı zamanda yüksek sıcaklık ve basınç değerlerine ulaşırlarsa kırılgan olabilmektedir. $\mathrm{Bu}$ kırılganlıklar sonucunda bu bölgelerde depremler meydana gelebilmektedir. Bir başka konu ise yüksek sıcaklık ve basınç değerlerinde kayaçların plastik deformasyona uğradığıdır. $\mathrm{Bu}$ nedenle bir elastik plaka modelinin kullanımı, kabuğun ve mantonun uzun jeolojik çağlar boyunca davranıș șekillerini daha anlașılır hale indirgemektedir [16].

Elastik plakanın bükülme rijiditesi $D$, plakanın yükü dengelemesini sağlayan parametredir [33]. Eğer rijidite $D$, sıfıra yaklaşırsa dengeleme mekanizması Airy modeline yaklaşmaktadır, bir başka deyişle lokal dengeleme mekanizması çalışmaktadır. Bükülme rijiditesi, yeryuvarının efektif elastik kalınlık $\left(T_{e}\right)$ değeri ile ilişkilidir ve $D$,

$D=E \frac{T_{e}^{3}}{12\left(1-v^{2}\right)}$

șeklinde tanımlanmaktadır [33]. Bağıntıda $E$ Young modülü, $v$ poisson oranı, $T_{e}$ efektif elastik kalınlık olarak verilir. 
Kabuk ve manto malzemeleri için sık kullanılan sınır koșulu tek eksenli gerilme koșuludur. Bu duruma göre bir eksen boyunca zorlanma mevcut iken diğer iki eksende zorlanma yoktur. $\mathrm{Bu}$ gerilimler arasındaki ilişki;

$\sigma_{2}=\sigma_{3}=\frac{v}{(1-v)} \sigma_{1}$

şeklinde verilir [16]. Jeolojik uygulamalarda $\sigma_{1}$, gravite yönündeki yani düșey yöndeki gerilmeyi gösterirken $\sigma_{2}$ ve $\sigma_{3}$ ortogonal yatay gerilmelerdir. Bir kayaca etkiyen düşey gerilme bu kayacın üzerindeki örtü tabakasının basıncına bağlı ise;

$\sigma_{1}=\rho g h$

bağıntısıyla tanımlanır. Burada h; kayacın derinliği, $\rho$ ise kayacın yoğunluğudur. Eğer bu kayaç sadece düșey yönde hareket edebiliyorsa bağıntı (3), bağıntı (2)' de yerine konur ve

$$
\sigma_{2}=\sigma_{3}=\frac{v}{(1-v)} \rho g h
$$

ifadesi elde edilir.

Bükülmeyi modelleyebilmek için yatay yönde büyük boyutlara sahip ancak düșey yönde ince olan plakaların eğilmesine uygun basit bir teori geliștirilmiștir. Uzunluğu genișliğinin 3 katı olan bir plakaya iki köşesinden yükleme yapılması sonucunda meydana gelen bükülmenin silindirik olduğu belirtilmiștir [34]. Böylelikle, yer kabuğu ve manto deformasyonunun modellenmesinde plaka yerine birim genișliğe sahip bir kiriș kullanılabilmektedir. Bu modellemede, iki uçtan uygulanan döndürme momenti tarafindan deforme olan bir elastik kiriș içindeki gerilmeler göz önüne alınırsa (Şekil 2) dönme momentleri kiriși aşağıya doğru konveks bir șekilde deforme etmektedir. Burada, deformasyonun kirișin herhangi bir düşey kesitinde eğilme öncesi ve sonrasında aynı olacağı varsayılmaktadır. Şekil 2'deki $A B C$ ve CEF üçgenlerinin benzerliğinden, kiriş içindeki herhangi bir elemanın $x$ yönündeki deformasyonu:

$\varepsilon_{x}=\frac{E F}{B C}=\frac{C F}{A C}=\frac{y_{f}}{r}=\frac{\text { değisisim }}{\text { orjinal uzunluk }}$

bağıntısı ile verilmektedir. Burada; $r$ eğrilik yarıçapı, $y_{f}$ nötr yüzeyden kiriș içindeki herhangi bir elemana olan uzaklıktır.

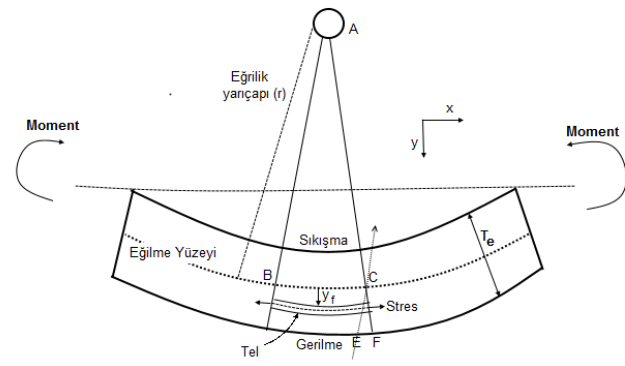

Şekil 2. Bir kirişin elastik bükülmesi [16]'den değiştirilerek alınmıştır.

Bu kiriş, sınır koşulları uygulanarak daha büyük bir plakanın bir parçası olarak düşünülebilir. Bu durumda kiriș $x$ ve $z$ yönlerinde stres altındadır ancak $y$ yönünde hareket edebilmektedir. $x$ yönündeki gerilme eğilmeden kaynaklanırken $z$ yönündeki gerilme bu yöndeki etkiyi önlemeye çalışmaktadır ve böylece daha büyük çaptaki bir plakanın etkisini yansıtmaktadır [16]. Buradaki elastik kalınlık tanımından yararlanarak, litosferik bükülmelerin hesaplanmasında kullanılan girişim (admittance) fonksiyonu geliştirilmiştir.

\subsection{Girişim (Admittance) fonksiyonu:}

Girișim fonksiyonu $Z(k)$, gravite $G(k)$ and topoğrafya $T(k)$ verilerinin Fourier dönüșümleri arasındaki ilişkinin analizi ile elde edilir ve girișim fonksiyonu;

$Z(k)=\frac{\sum_{r=1}^{N} G_{r}(k) T_{r}^{*}(k)}{\sum_{r=1}^{N} T_{r}(k) T_{r}^{*}(k)}$

bağıntısı ile verilmektedir [18]. Burada $k$ dalgasayısı ( $2 \pi$ /dalgaboyu), ${ }^{*}$ karmaşık eşleniği belirtir. Bu bağıntıda $N$ aynı örnekleme aralığına sahip yerçekimi ve topoğrafya haritalarından eşit uzunlukta alınan profillerdeki veri sayısıdır. Genellikle, bükülme modeli için kullanılan kuramsal girişim değerleri;

$Z_{t}(k)=\frac{2 \pi G \rho_{k}\left[1-\left(e^{-k T} d\right)\right]}{A}$

şeklinde verilmektedir [35]. Burada;

$A=1+\frac{D k^{4}}{g\left(\rho_{m}-\rho_{k}\right)} \quad D=E \frac{T_{e}^{3}}{12\left(1-\sigma^{2}\right)}$ 
$D$ rijidite, $G$ yerçekimi sabiti, $E$ Young modülü $\left(10^{11} \mathrm{~Pa}\right), \sigma$ Poisson oranı $(0.25), g$ yerçekimi ivmesi $\left(9.8 \mathrm{~m} / \mathrm{s}^{2}\right), \rho_{k}$ kabuğun ortalama yoğunluğu, $\rho_{m}$ esnek (bükülen) elastik plakanın altındaki malzemenin yoğunluğu, $T_{d}$ dengelemenin efektif kalınlığı, $T_{e}$ efektif elastik kalınlık ve $Z_{t}(k)$ kuramsal girişim fonksiyonudur.

\subsection{Uyum (Coherence) analizi}

Eğer rijiditesi sıfır olmayan sonlu bir plaka, yüzeyaltı ve yüzeyüstü yüklemeden kaynaklı iki ilişkisiz durum ile deforme edilirse, topoğrafya ve gravite arasındaki uyum veya istatistiksel ilişki plakanın rijiditesi hakkında bilgi sahibi olmamızı sağlamaktadır [36]. Girişim fonksiyonunu, efektif elastik kalınlık kestirimde kullanabilmek için, uyum (coherence) analizi yapmak önemlidir. Uyum analizinde gravite ile topoğrafya anomalileri arasındaki uyum gözlenmektedir. Yapılan uyum analizi sonucunda elde edilen sonuçlarda uyumun 1 ve 1'e yakın genliklerdeki frekans aralıkları $T_{e}$ hesap yorumlarında kullanılan frekans aralıklarıdır. Bu uyum $\left(\gamma^{2}\right)$;

$\gamma^{2}(k)=\frac{C(k) C^{*}(k)}{E_{0}(k) E_{1}(k)}$

bağıntısıyla verilmektedir [18]. Burada $C$ gravite anomalisi ile topoğrafyanın çapraz spektrumu, $E_{0}$ gravite anomalisinin güç spektrumunu, $E_{1}$ topoğrafyanın güç spektrumunu ifade etmek üzere,

$$
\begin{aligned}
& C(k)=\frac{1}{N} \sum_{r=1}^{N} G_{r}(k) T^{*}(k) \\
& E_{0}(k)=\frac{1}{N} \sum_{r=1}^{N} G_{r}(k) G_{r}^{*}(k) \\
& E_{1}(k)=\frac{1}{N} \sum T_{r}(k) T_{r}^{*}(k)
\end{aligned}
$$

olarak verilmiştir. Yüzey ve yüzeyaltı yüklerinin hesaba katılması sonucunda elde edilen kuramsal uyum analizi ile efektif elastik kalınlık hesabına geçilmektedir ve uyum analizi,

$$
\gamma^{2}=\frac{\left\langle H_{t} W_{t}+H_{b} W_{b}\right\rangle^{2}}{\left\langle H_{t}^{2} H_{b}^{2}\right\rangle\left\langle W_{t}^{2} W_{b}^{2}\right\rangle}
$$

şeklinde tanımlanmaktadır [36]. Burada; 〈 > spektral ortalamayı, $H_{t}$ yüzey yüklerinin, $H_{b}$ yüzeyaltı yüklerini etkilediği topoğrafyayı, $W_{t}$ yüzey yüklerinin, $W_{b}$ yüzeyaltı yüklerinin neden olduğu bükülmeyi ifade etmektedir.

2.4 Kabuk-Manto arayüzeyi yük modellemesi düz çözüm yöntemi ve gravite modellemesi ters çözüm yöntemi ile kestirimi:

\subsubsection{Yük modellemesi düz çözüm yöntemi}

Uzun jeolojik zaman ölçeğindeki yüklere karşı litosferin gösterdiği dengeleme Airy ve Pratt modellerinin ileri sürdüğü gibi lokal olmamakta, dengeleme geniş alanlarda rejyonal olarak meydana gelmektedir. Böylece litosfer kısa dalga boylu deformasyonları bastıran, uzun dalga boylu deformasyonları geçiren bir filtre görevi görmektedir. Elastik bir plakanın üzerine yüklenen yüke karşı verdiği yanıt genel olarak,

$$
D \frac{\partial^{4} y}{\partial x^{4}}+\left(\rho_{m}-\rho_{d}\right) y g=\left(\rho_{k}-\rho_{o}\right) g h \cos (k x)
$$

bağıntısı ile verilmektedir. Burada $y$ bükülme, $x$ yatay uzaklık, $\rho_{m}$ esnek (bükülen) elastik plakanın altındaki malzemenin yoğunluğu, $\rho_{d}$ bükülen kısmı dolduran malzeminin yoğunluğu, $\rho_{k}$ kabuğun ortalama yoğunluğu, $\rho_{o}$ yükün bulunduğu ortamın yoğunluğudur (örn. su veya hava). Bağıntı (13) düzenlenirse;

$y=\frac{\left(\rho_{k}-\rho_{o}\right) h \cos (k x)}{\left(\rho_{m}-\rho_{d}\right)}\left[\frac{D k^{4}}{\left(\rho_{m}-\rho_{d}\right) g}+1\right]^{-1}$

elde edilir.

Herhangi bir $\mathrm{P}$ noktasındaki gravite anomalisinin Fourier dönüşümü $F T\left[\Delta g_{p}(\vec{r})\right]$ ile $\mathrm{P}$ noktasindan $d$ kadar uzakta olan Q noktasındaki gravite anomalisinin Fourier dönüşümü $F T\left[\Delta g_{Q}(\vec{r})\right]$ arasında bir ilişki kurulmuştur [37] ve bu ilişki,

$F T\left[\Delta g_{p}(\vec{r})\right]=e^{-(\vec{k}) d} F T\left[\Delta g_{Q}(\vec{r})\right]$

bağıntısı ile verilir. Burada $\vec{r}=r(x, y)$ uzay ortamında 2 boyutlu vektördür ve $(\vec{k})=k\left(k_{x}, k_{y}\right)$ frekans ortamında dalga sayısıdır. $F T\left[\Delta g_{Q}(\vec{r})\right]$ denk yüzey kütlesinde $M_{Q}[\vec{k}]$ yerine konursa,

$M_{Q}[\vec{k}]=\frac{F T\left[\Delta g_{Q}(\vec{r})\right]}{2 \pi G}$ 
bağıntısı elde edilir ve $M_{Q}[\vec{k}]$ yüzey kütlesidir ve buradan;

$F T\left[\Delta g_{p}(\vec{r})\right]=2 \pi G(\Delta \rho) H(\vec{k})$

bağıntısına ulaşılır. Burada $H(\vec{k})$ topoğrafyanın Fourier dönüșümü, $\Delta \rho$ yoğunluk farkıdır. Eğer bağıntı (17), bağıntı (15)' de yerine konursa;

$F T\left[\Delta g_{p}(\vec{r})\right]=2 \pi(\Delta \rho) e^{-|\vec{k}| d} H(\vec{k})$

elde edilir.

Böylelikle, $Z(k)$ topoğrafyayı kompanse eden yapının neden olduğu gravite anomalisini olușturan dalga sayısı parametresidir ve bu parametre izostazinin hakkında bilgi içermektedir:

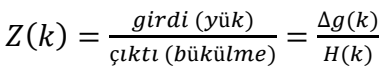

bağıntısıyla verilmektedir.

\subsubsection{Gravite modellemesi ters çözüm yöntemi}

Gravite verisinin ters çözümünü hesaplamak için başlangıç parametreleri olarak referans derinlik $(d)$ ve arayüzeydeki yoğunluk farkı $(\Delta \rho)$ parametreleri gereklidir. $g_{o}$ kartezyen koordinatlarda Bouguer gravite alanı ise $g_{d} d$ derinliğine doğru așağı alanalitik uzanım alanını ifade etmektedir ve bu iki alanın arasındaki ilişki;

$$
F T\left[g_{d}\right]=e^{d \sqrt{k_{x}^{2}+k_{y}^{2}}} F T\left[g_{o}\right]
$$

bağıntısı ile verilmektedir. Burada $k_{x}, k_{y}$ kartezyen koordinatlarda dalga sayısıdır. Buradaki gravite alanın $d$ derinliğindeki bir kütleden kaynaklandığı varsayılmaktadır. Gravite alanını olușturan bu kütle; yatay olarak değișen bir yüzey yoğunluğu $(\rho(x, y))$ olarak tanımlanabilir ve yoğunluk farkı $(\Delta \rho)$ ile iki tabakayı ayıran bir ondülasyon sınırı modeli ile ifade edilebilir [38]. Ondülasyon sınırı $r_{1}$;

$r_{1}(x, y)=\frac{1}{\Delta \rho} \rho(x, y)=\frac{1}{\Delta \rho} \frac{1}{2 \pi G} g_{d}(x, y)=$

$\frac{1}{\Delta \rho} \frac{1}{2 \pi G} F T^{-1}\left[F T\left[g_{d}\right]\right]$

bağıntısı ile verilmektedir.

\section{Uygulamalar:}

Bu çalışmada $23^{\circ}-32^{\circ} \mathrm{K}$ boylamları ile $33^{\circ}-37^{\circ} \mathrm{D}$ enlemleri arasında kalan Doğu Akdeniz Bölgesi çalışma alanı olarak seçilmiştir. Doğu Akdeniz Bölgesi'ne ait topoğrafya/batimetri haritası (Şekil 1) incelendiğinde bölgede farklı topoğrafik/batimetrik özelliğe sahip ortamların bulunması ve jeolojik olarak farklı kökene ve farklı gravite değerlerine sahip olan bölge; kendi içinde benzer özelliklere sahip iki ayrı çalıșma bölgesine ayrılmıștır (Şekil 3). Çalıșmanın ilk aşamasında [39]' ndan elde edilen Bouguer gravite anomali haritası oluşturulmuştur (Şekil 4).

Rezidüel gravite alanı, $g_{o}(x, y)$ gözlem alanı ile $g_{1}(x, y)$ hesaplanan alanın farkı olarak ifade edilir $[37,38,40]$. Rezidüel alan $\left(\delta g_{1}(x, y)\right)$ bir çeşit düzeltme biçimidir ve bu alan yoğunluk sınırının ondülasyon büyüklüğüne etki etmektedir. $\mathrm{Bu}$ durum iterativ olarak devam etmekte ve her $k$ iterasyon adımında rezidüel gravite alanı $\left(\delta g_{k}(x, y)\right)$ ve sinırın ondülasyon büyüklüğü $\left(r_{k}(x, y)\right)$ elde edilmektedir. 


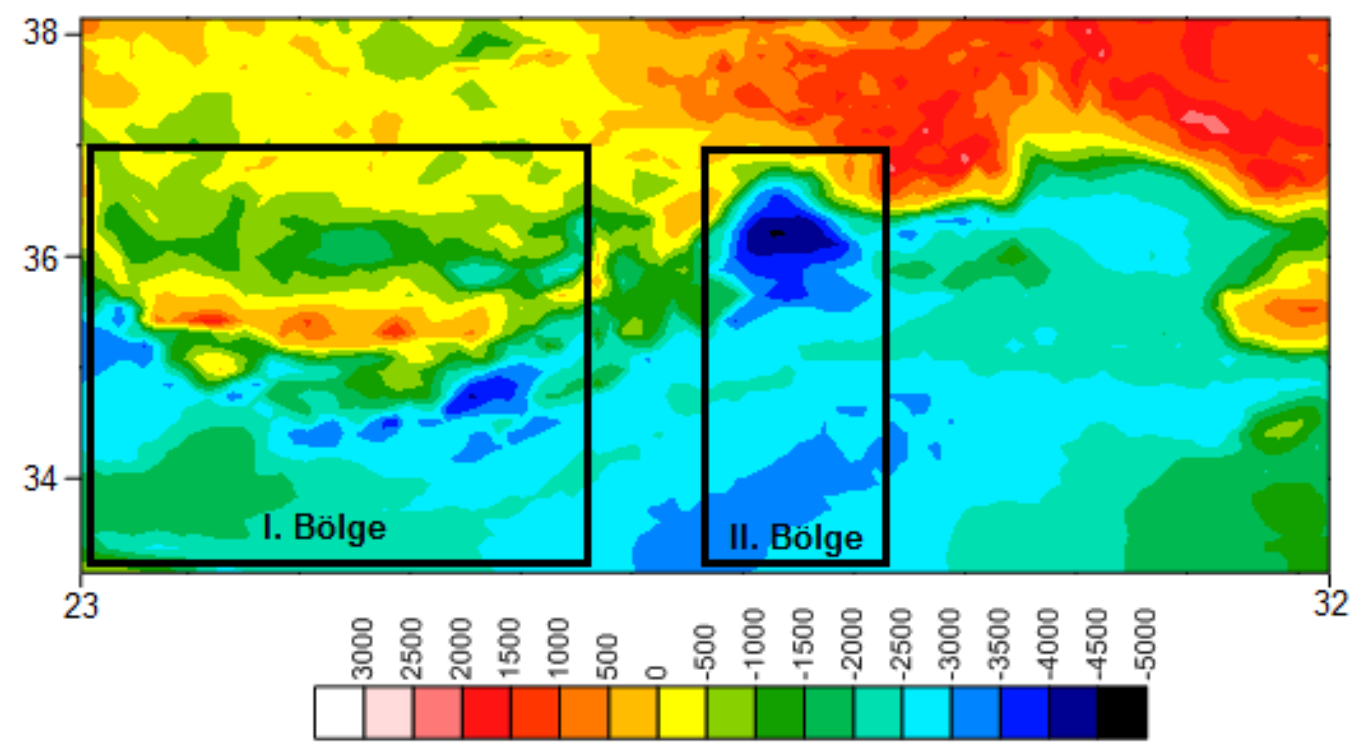

topoğrafya/batimetri $(\mathrm{m})$

Şekil 3. Doğu Akdeniz topoğrafya/batimetri haritası üzerinde iki çalışma bölgesinin gösterimi [32]

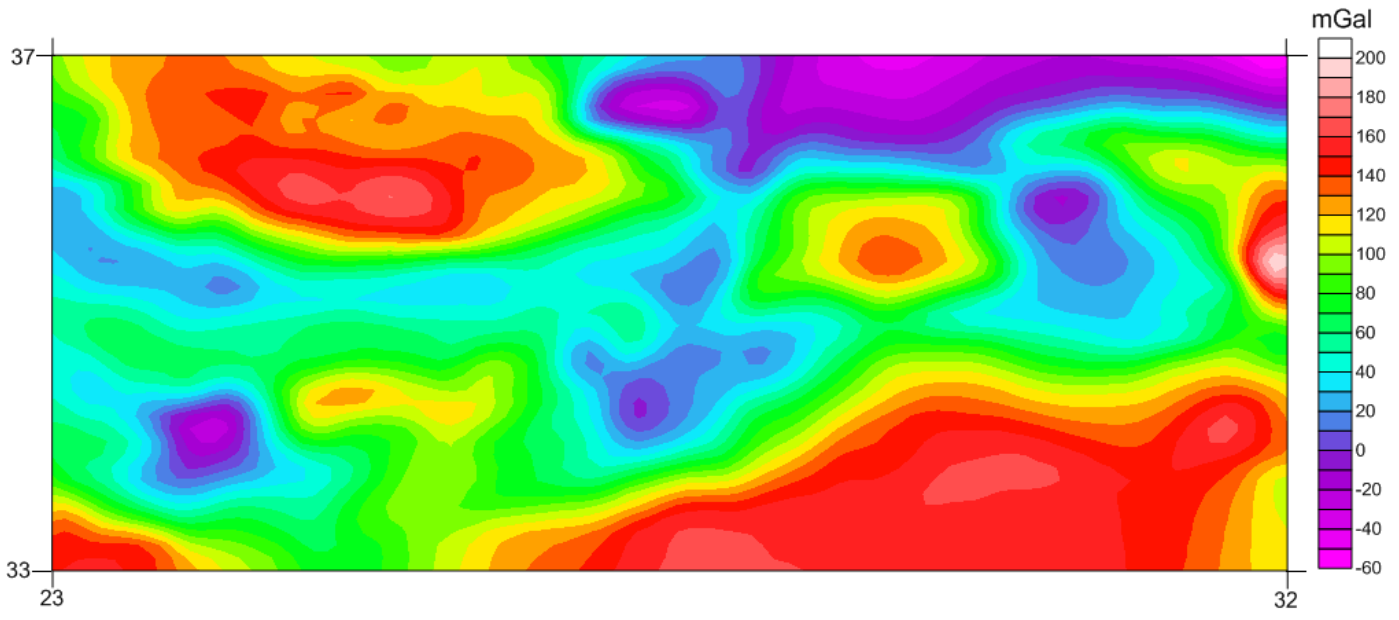

Şekil 4. $23^{\circ}-32^{\circ} \mathrm{K}$ boylamları ile $33^{\circ}-37^{\circ} \mathrm{D}$ enlemleri arasında kalan bölgenin Bouguer gravite anomali haritası [39].

\subsection{I.Bölge $\left(23.5^{\circ}-26.5^{\circ}\right.$ Boylamları, $33^{\circ}-37^{\circ}$ Enlemleri) uygulamaları:}

Girit Adası ve çevresini içeren I. Bölge uygulama alanına ait çalıșmaların ilk adımında topoğrafya (Şekil 3) verileri ile Bouguer (Şekil 4) gravite değerlerinin arasındaki uyumu saptayabilmek için (8) bağıntısı kullanılarak uyum analizi yapılmıştır (Şekil 5). En iyi uyumun $0.01<k<0.1$ (Şekil 5) aralığında olduğu saptanmış, böylelikle girişim fonksiyonu hesaplamaları bu dalga sayısı değerleri arasında değerlendirilmiştir.

I.bölge için yapılan girişim fonksiyonu uygulamalarında ortalama kabuk yoğunluğu $\rho_{c}=2.7 \mathrm{~g} / \mathrm{cm}^{3}$, ortalama manto yoğunluğu $\rho_{m}=3.3$ $\mathrm{g} / \mathrm{cm}^{3}$ [41] olarak alınmıștır. Kabuk kalınlığı 


\section{DEÜ FMD 22(65), 541-559, 2020}

parametresi için güç spektrumu yönteminden [42] yararlanılarak ortama ait yapı derinliği 30 $\mathrm{km}$ olarak hesaplanmıştır. Böylece I. bölge için yapılan uygulamalarda ortalama kabuk kalınlığı $T_{c}=30 \mathrm{~km}$ olarak belirlenmiștir.

Daha sonra Bouguer gravite ile topoğrafya verileri kullanılarak (6) bağıntısı ile gözlemsel girişim değerleri, (7) bağıntısı ile kuramsal girişim değerleri bu bölge için ilk olarak bu çalışma kapsamında hesaplanmıştır. Kuramsal girişim hesabında ise, $E=10^{11} \mathrm{~Pa}, \sigma=0.25, g=9.8$ $\mathrm{m} / \mathrm{s}^{2}, \rho_{c}=2.7 \mathrm{~g} / \mathrm{cm}^{3}, T_{c}=30 \mathrm{~km}$ değerleri kullanılmıștır. Kuramsal girișim değerleri ilk önce
$T_{e}=0,5,10,15$ ve $20 \mathrm{~km}$ değerleri için hesaplanmıştır (Şekil 6). Bu hesaplama sonucunda; gözlemsel ve kuramsal girișim değerleri arasındaki en iyi uyumun $T_{e}=5 \mathrm{~km}$ ile $T_{e}=10 \mathrm{~km}$ değerleri arasında olduğu görülmektedir (Şekil 6). Bu bulgudan yola çıkarak $T_{e}=3,5,6,7$ ve $8 \mathrm{~km}$ değerleri için tekrar kuramsal girișim değerleri hesaplanmıștır (Şekil 7). Böylece, kuramsal girişim değerleri ile gözlemsel girişim değeri arasında en iyi uyumu veren efektif elastik kalınlığın ortalama $6 \mathrm{~km}$ olduğu saptanmıștır.

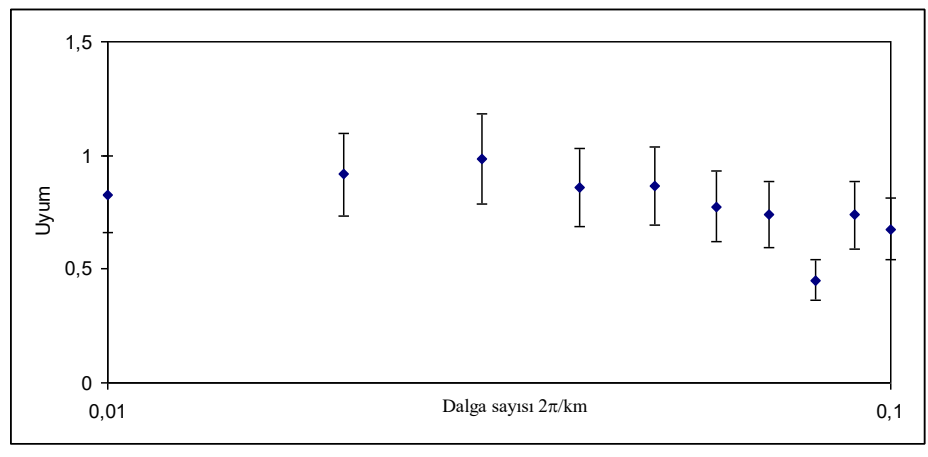

Şekil 5. Bouguer ve topoğrafya verileri arasındaki uyum.

Bu uygulamanın ikinci adımında yüklemelerden kaynaklanan bükülme yüzeylerini saptamaya yönelik farklı $T_{e}$ değerleri $\left(T_{e}=2,6,12 \mathrm{~km}\right)$ için düz çözüm uygulamaları yapılmıștır (Şekil 8.a.b.c). Burada $E=10^{11} \mathrm{~Pa}, \sigma=0.25, \rho_{c}=2.7$ $\mathrm{g} / \mathrm{cm}^{3}, \rho_{m}=3,3 \mathrm{~g} / \mathrm{cm}^{3}, g=9.8 \mathrm{~m} / \mathrm{s}^{2}$ olarak alınmıștır. Ancak uygulamada kullanılacak uygun referans derinlik değerini saptamak için çeşitli derinlikler denenmiştir. Denemelerin amacı gravite ters çözümü ile elde edilen ondülasyon sınırı değerleri ile bu uygulamadan elde edilecek bükülme yüzeyi değerleri arasında uyumun sağlanabilmesidir. Yapılan denemelerde düz çözüm için referans derinlik (Moho derinliği) $28 \mathrm{~km}$ seçildiğinde bu uyumun sağlandığı saptanmıștır. Bükülme yüzeyi hesaplamaları için yapılan düz çözüm uygulamalarında kullanılan topoğrafya verisi sadece yüzey yüklerini içermektedir. Bundan dolayı çıkan sonuçlar sadece yüzey üstü yüklerinin meydana getirdiği bükülme yüzeylerini temsil etmektedir. Verilen parametreler ile $T_{e}=2,6$ ve $12 \mathrm{~km}$ için yaratılan bükülme yüzeyleri haritaları Șekil 8.a, 8.b ve 8.c'de görülmektedir.

Daha sonra LithoFLEX 1.2 yazılımı yardımıyla $23.5^{\circ}-26.5^{\circ}$ Boylamları ve $33^{\circ}-37^{\circ}$ Enlemleri arasında kalan I. bölgeye ait bouguer gravite değerleri ile gravite ters çözümü yapılmış ve kabuk-manto ara yüzeyinin derinliği tespit edilmiștir. $\mathrm{Bu}$ uygulamada kabuk-manto arasındaki yoğunluk farkı $0.6 \mathrm{~g} / \mathrm{cm}^{3}$ ve referans (Moho) derinliği $30 \mathrm{~km}$ olarak kullanılmıştır. Gravite ters çözüm uygulamaları çeşitli kesme dalga boyu (100 km ve $75 \mathrm{~km})$ ve 1 . ve 3 . iterasyon için hesaplanmıș, en iyi uyumu veren değerlerin dalga boyu $100 \mathrm{~km}$ ve 1 . iterasyon ile elde edilen değerleri olduğu saptanmıștır (Şekil 9) 
DEÜ FMD 22(65), 541-559, 2020

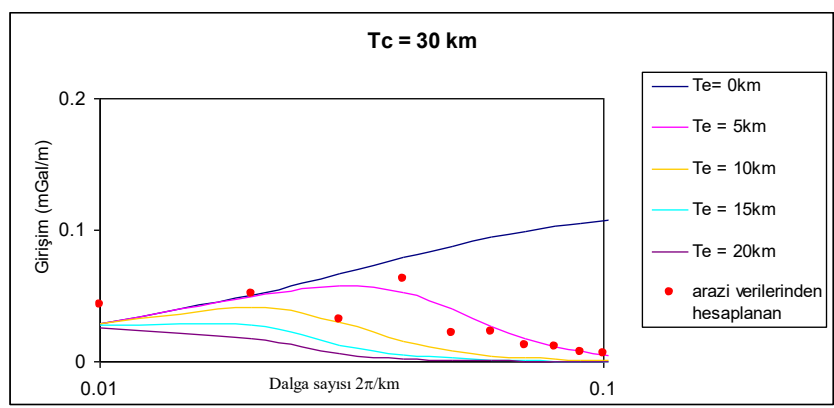

Şekil 6. Bouguer gravite değerleri için hesaplanan gözlemsel girişim ile çeșitli $T_{e}$ değerleri için hesaplanan kuramsal girişim değerlerinin görünümü.

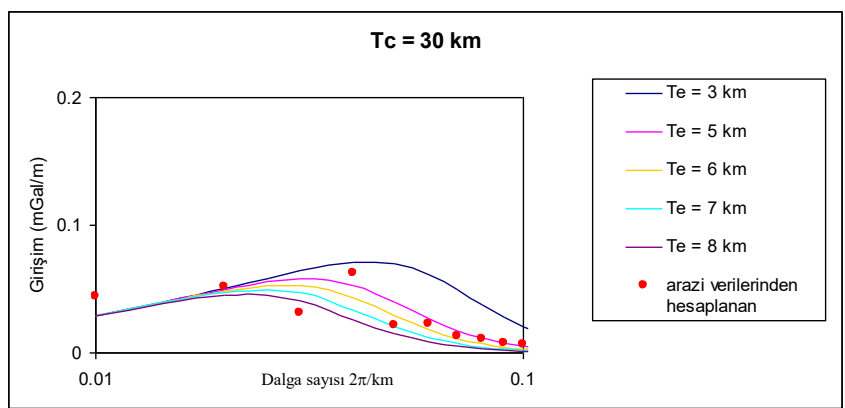

Şekil 7. Bouguer gravite değerleri için hesaplanan gözlemsel girişim ile çeşitli $T_{e}$ değerleri için hesaplanan kuramsal girișim değerlerinin görünümü.

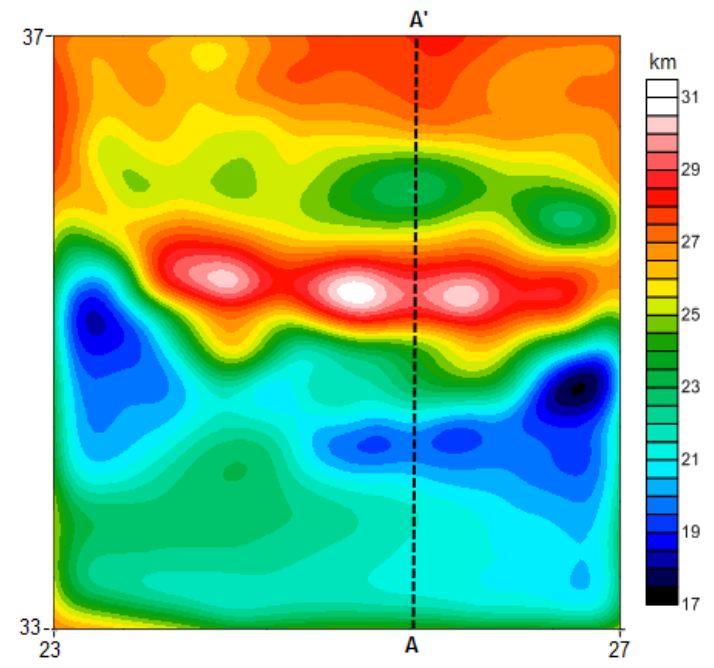

Şekil 8.a $T_{e}=2 \mathrm{~km}$ ve referans derinliği (Moho derinliği) $28 \mathrm{~km}$ için hesaplanan bükülme yüzeyi haritası. 


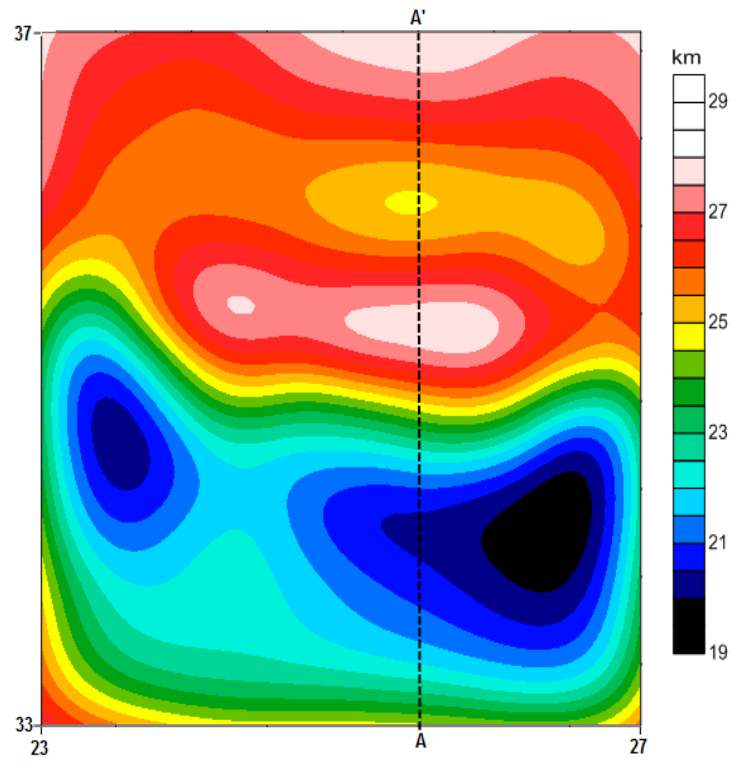

Şekil 8.b $T_{e}=6 \mathrm{~km}$ ve referans derinliği (Moho derinliği) $28 \mathrm{~km}$ için hesaplanan bükülme yüzeyi haritası.

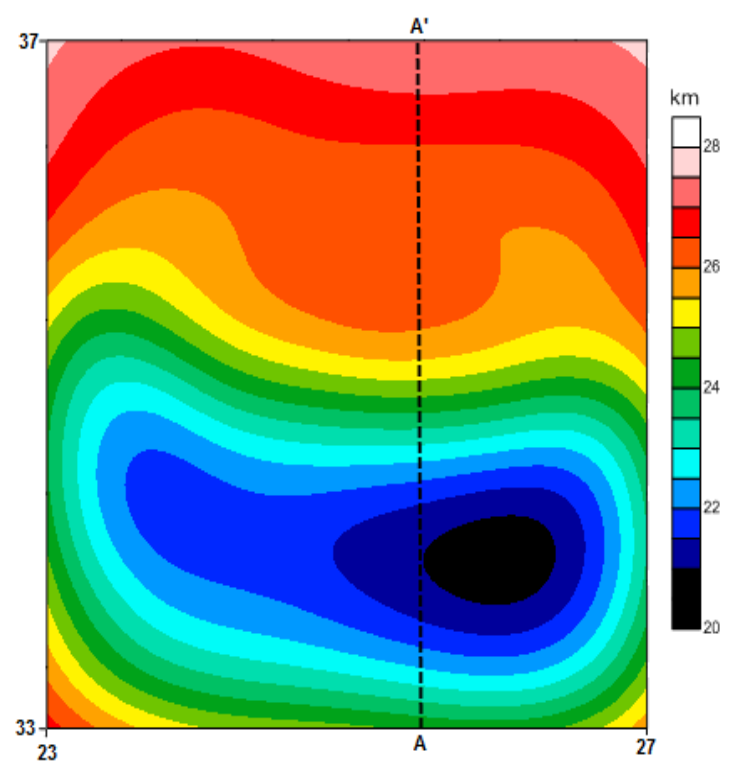

Şekil 8.c $T_{e}=12 \mathrm{~km}$ ve referans derinliği (Moho derinliği) $28 \mathrm{~km}$ için hesaplanan bükülme yüzeyi haritasl. 
DEÜ FMD 22(65), 541-559, 2020

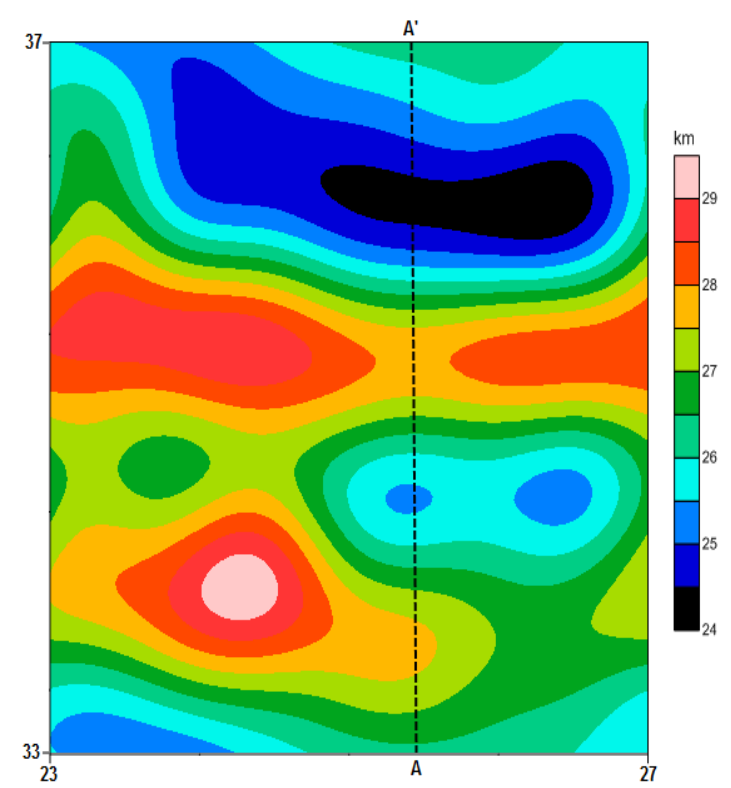

Şekil 9. Kesme dalga sayısı $100 \mathrm{~km}$ ve 1 . iterasyon sayısı için elde edilen kabuk-manto ara yüzeyi derinliği haritası 3.2 II. Bölge $\left(28^{\circ}-29.5^{\circ}\right.$ Boylamları, $33^{\circ}-37^{\circ}$
Enlemleri) Uygulamaları

Girit Adası ve çevresini içiren I.Bölge için yapılan uygulamalar, Rodos baseni ve çevresini içeren II. Bölge olarak adlandırılan $28^{\circ}-29.5^{\circ}$ Boylamları ve $33^{\circ}-37^{\circ}$ Enlemleri arasındaki bölge (Şekil 3) için de yapılmıştır. Topoğrafya ve Bouguer gravite verileri arasındaki uyum analizi sonucunda (Şekil 10 ), en iyi uyumun $0.01<k<0.1$ aralığında olduğu saptanmıș, böylece girișim fonksiyonu hesaplamaları bu dalga sayısı değerleri arasında değerlendirilmiştir. Ardından, güç spektrumu yöntemi ile yapı derinliği hesaplaması yapılmış ve ortama ait yapı derinliği $26 \mathrm{~km}$ bulunmuştur. Sonuç olarak II. bölge için yapılan uygulamalarda ortalama kabuk kalınlığı $T_{c}=26 \mathrm{~km}$ olarak alınmıștır.

Bir sonraki adımda ilk olarak Bouguer gravite değerleri için kuramsal girişim değerleri hesaplanmış, bu hesaplamada ortalama $\rho_{c}=2.7$ $\mathrm{g} / \mathrm{cm}^{3}$, ortalama $\rho_{m}=3.3 \mathrm{~g} / \mathrm{cm}^{3}$ [43] olarak alınmış ve $T_{c}=26 \mathrm{~km}, E=10^{11} \mathrm{~Pa}, \sigma=0.25, g=$
$9.8 \mathrm{~m} / \mathrm{s}^{2}$ değerleri kullanılmıştır. Kuramsal girișim değerleri $T_{e}=0,3,5,10$ ve $15 \mathrm{~km}$ değerleri için hesaplanmıştır. Burada en iyi uyumu veren değerlerin $5 \mathrm{~km}$ ile $10 \mathrm{~km}$ arasında oldukları görülmektedir (Şekil 11).

İkinci așamada yüklemelerden kaynaklanan bükülme yüzeylerini saptamaya yönelik $\mathrm{T}_{e}=2,8$, $14 \mathrm{~km}$ değerleri için referans (Moho) derinlik 30 km alınarak bükülme düz çözüm uygulamaları yapılmıştır (Şekil 12.a,b,c,). Daha sonra, II. bölge için Bouguer gravite değerleri ile gravite ters çözümü yapılarak, kabuk-manto ara yüzeyinin derinliği tespiti yapılmıştır. Gravite ters çözümü uygulamasında için kabuk manto arasındaki yoğunluk farkı $0.6 \mathrm{~g} / \mathrm{cm}^{3}$ ve referans derinlik (Moho derinliği) $26 \mathrm{~km}$ olarak kullanılmıș, çeșitli kesme dalga boyu (100 km ve $75 \mathrm{~km})$ ve 1 . ve 3 . iterasyon için ondülasyon sınırı hesaplanmıştır ve en iyi uyumun 1. iterasyonda ve kesme dalga boyu 100 km iken olduğu görülmüştür (Şekil 13). 
DEÜ FMD 22(65), 541-559, 2020

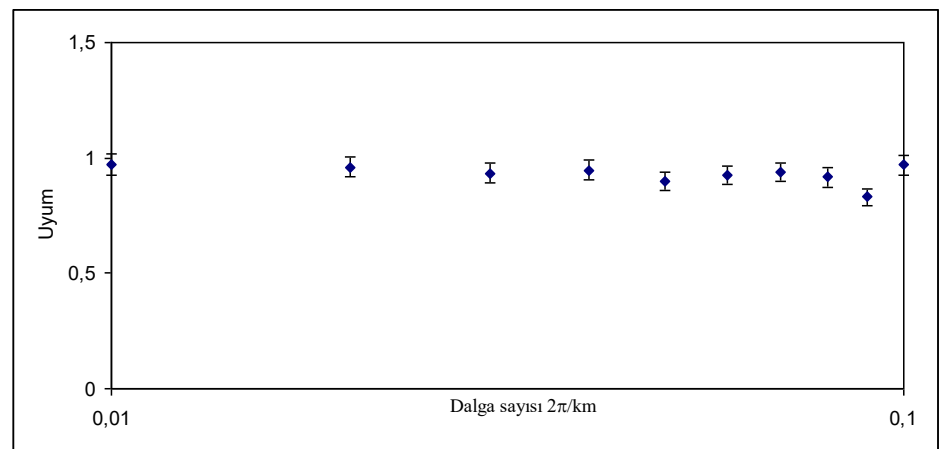

Şekil 10. Bouguer ve topoğrafya verileri arasındaki uyum.

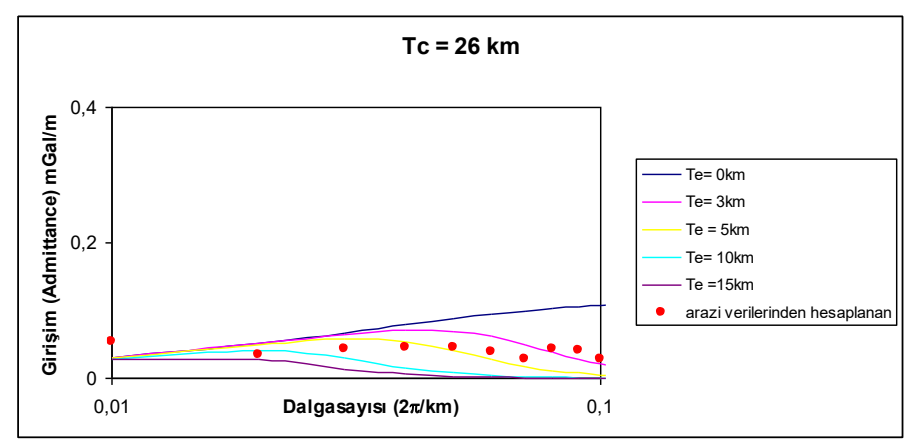

Şekil 11. Bouguer gravite değerleri için hesaplanan gözlemsel girișim ile çeșitli Te değerleri için hesaplanan kuramsal girişim değerlerinin görünümü.

\section{Tartışma ve Sonuç}

Doğu Akdeniz Bölgesi, Avrasya ve Afrika plakalarının çarpışmasının bir parçasıdır ve bölge okyanus ve kitasal kabuğun birarada bulunduğu çok karmaşık bir alandır. Çok sayıdaki araştırmacı [örn.; 11, 41, 43-67] bu karmaşık tektonizmayı jeolojik ve jeofiziksel çalışmalar ile irdelemişlerdir. Bu çalışmalardan Girit adası ve çevresini içeren sismik çalışmalar $[13,58]$ bu bölgeye ait kabuk kalınlığın sırasıyla $32-34 \mathrm{~km}$ ve $30 \mathrm{~km}$ olduğunu belirtmektedir.

Levha tektoniğinin en önemli konusu, litosferin kalınlığı ve uzun jeolojik zamanlar boyunca nasıl davrandığıdır. İzostazi kavramının gelişmesiyle, levha tektoniğinin temel varsayımlarından olan uzun zaman ölçeğinde levhaların rijit olarak davrandığı gerçeği öne sürülmüştür. Böylelikle izostazi kavramı, litosferin tanımlanmasında önemli bir dönüm noktası olmuştur. Bükülme modeli olarak tanımlanan rejyonel bükülme modelinde yükler, akışkan ve zayıf astenosferin üzerinde bulunan litosferik plakadaki elastik gerilmeler (stresler) ile desteklenmektedir [6567]. Bu bükülme modeline göre, büyük yüklerin etki ettiği bölgelerde litosfer eğrilir ve kabuksal kalınlık o ortama ait olması beklenen kalınlıklara göre daha incedir. Bunun sonucunda, plakaların bükülmeye uğrayan alt ve üst kısımlarında gerilmeler görülür [16]. Bu gerilmelerin olduğu kısımlar bölgede meydana gelen depremlerin yaklaşık odak derinlik dağılımlaraına işaret edeceğinden, plaka bükülmelerinin meydana geldiği derinliklerinin ve plakaların elastik kalınlıklarının belirlenmesi olası depremlerin yaklaşık derinliklerinin kestirilmesi konusunda önemli bir kavramdır.

Bu çalışma ile efektif elastik kalınlık kestirimleri için kullanılan izostatik yanıt fonksiyonları ile litosferin yapısını anlamaya yönelik yeni 
DEÜ FMD 22(65), 541-559, 2020

yaklașımlar getirilmiştir ve bu bölgenin efektif elastik kalınlığını saptamaya yönelik çalışmalar ilk olarak bu çalıșma kapsamında yapılmıștır. Bir bölgeye ait efektif elastik kalınlık kestirimi çalışmalarında başarı oranının yüksek olabilmesi için izostatik yanıt fonksiyonları ile birlikte kabuk-manto sınırı bükümsel olarak efektif elastik kalınlık çalışmaları tektonik, sismolojik ve diğer derin jeofizik çalıșmalar ile desteklenmelidir. Yapılan uygulamalar, Doğu Akdeniz bölgesinin izostatik modellerinin Airy modeline $\left(T_{e}=0\right)$ uymadığını göstermektedir.

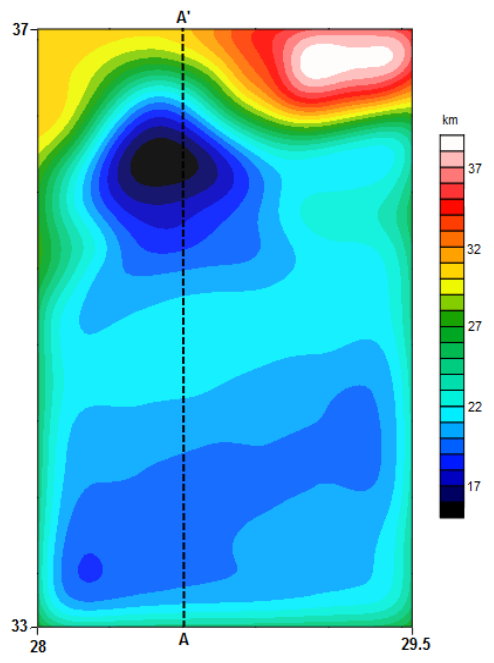

Şekil 12.a $T_{e}=2 \mathrm{~km}$ ve referans derinlik (Moho derinliği) $30 \mathrm{~km}$ için hesaplanan bükülme yüzeyi haritası.

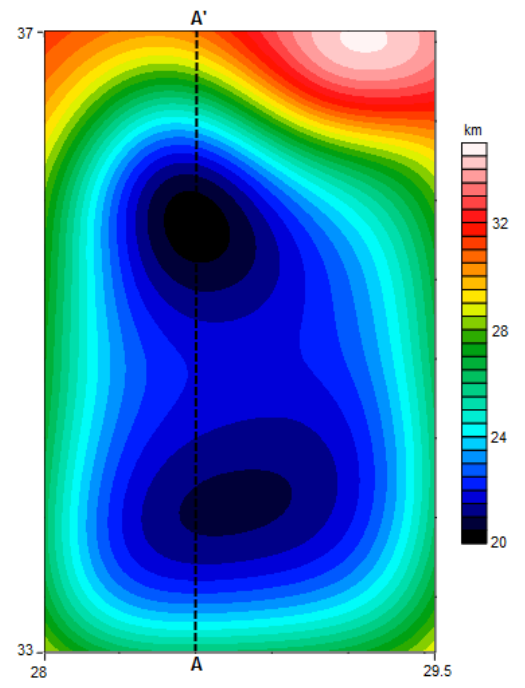

Sekil 12.b $T_{e}=8 \mathrm{~km}$ ve Moho derinliği $30 \mathrm{~km}$ için hesaplanan bükülme yüzeyi haritası. 
DEÜ FMD 22(65), 541-559, 2020

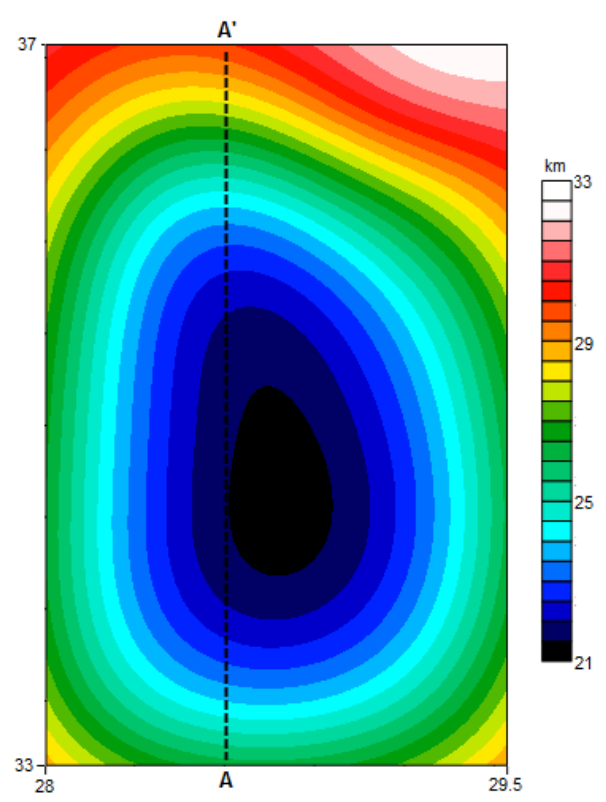

Şekil 12.c $T_{e}=14 \mathrm{~km}$ ve Moho derinliği $30 \mathrm{~km}$ için hesaplanan bükülme yüzeyi haritası.

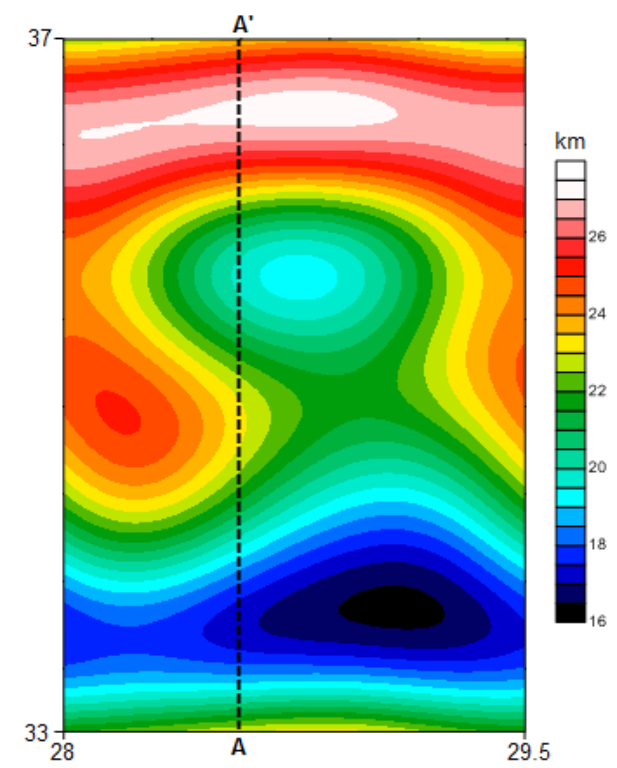

Şekil 13. Kesme dalga sayısı $100 \mathrm{~km}$ ve 1 . iterasyon için elde edilen kabuk-manto ara yüzeyi derinliği haritası 


\section{DEÜ FMD 22(65), 541-559, 2020}

Bu çalışmada $23^{\circ}-32^{\circ} \mathrm{K}$ boylamları ile $33^{\circ}-37^{\circ} \mathrm{D}$ enlemleri arasında kalan Doğu Akdeniz Bölgesi çalıșma alanı olarak seçilmiș ancak bölge; fiziksel, topoğrafyafik ve batimetrik olarak farklı özelliğe sahip ortamları ve jeolojik olarak farklı kökene sahip bölgeleri içermesinden dolayı Girit adası çevresi ve Rodos baseni çevresi olmak üzere iki ayrı bölge olarak çalışılmıştır.

$23.5^{\circ}-26.5^{\circ}$ Boylamları ve $33^{\circ}-37^{\circ}$ Enlemleri arasında kalan Girit Adası ve çevresini içeren I. bölgeye ait çalışmaların ilk adımında gravite ve topoğrafya verileri arasındaki uyum analizi sonucunda en iyi uyumun sirasılya; $0.01<k<$ 0.1 dalgasayı $(k)$ değerleri arasında olduğu saptanmış, girişim fonksiyonu hesaplamaları bu dalga sayısı değerleri arasında değerlendirilmiștir. Kabuk kalınlığı parametresi için güç spektrumu yöntemi ile ortama ait yapı derinliği $30 \mathrm{~km}$ olarak hesaplanmış, I. bölge için yapılan uygulamalarda ortalama kabuk kalınlığ $T_{c}=30 \mathrm{~km}$ olarak belirlenmiștir. Aynı çalıșma alanında yapılan Normalize Tam gradiyent çalışmasında [15] 30 km derinliğindeki kabuğu Afrika Okyanusal kabuğu olarak tanımlamıștır. Buradan hareketle bu bölgede elastik kalınlık hesaplamalarında Afrika okyanusal kabuğu etkindir.

Ardından, Bouguer gravite ile topoğrafya verileri kullanılarak gözlemsel girişim değerleri ile kuramsal girișim değerleri irdelenmiștir. Kuramsal girişim değerleri ilk önce $T_{e}=0,5,10$, 15 ve $20 \mathrm{~km}$ değerleri için hesaplanmış, gözlemsel ve kuramsal girişim değerleri arasındaki en iyi uyumun $T_{e}=5 \mathrm{~km}$ ile $T_{e}=10 \mathrm{~km}$ değerleri arasında olduğu saptanmıştır. Elastik kalınlık değerini daha ayrıntılı irdelemek için $T_{e}$ $=3,5,6,7$ ve $8 \mathrm{~km}$ değerleri için tekrar kuramsal girişim değerleri hesaplanmış, kuramsal girişim değerleri ile gözlemsel girișim değeri arasında en iyi uyumu veren efektif elastik kalınlığın I. Bölge için ortalama $6 \mathrm{~km}$ olduğu saptanmıştır. Bölgeye ait efektif elastik kalınlık saptamasına yönelik uygulamaların ikinci aşamasında ise gravite ters çözüm ve bükülme düz çözümü hesaplamaları yapılmıștır. Yüklemelerden kaynaklanan bükülme yüzeylerini saptamaya yönelik farklı $T_{e}$ değerleri $\left(T_{e}=2,6,12 \mathrm{~km}\right)$ için düz çözüm uygulamaları yapılarak yüzeyüstü yüklerinin meydana getirdiği bükülme yüzeyleri elde edilmiştir. Ardından LithoFLEX 1.2 yazılımı kullanılarak Bouguer gravite değerleri ile gravite ters çözümü yapılmış ve kabuk-manto arayüzeyinin derinliği saptanmıștır. Gravite ters çözüm ve bükülme düz çözümü hesaplamalarından çlkan sonuçları karşılaștırmak için Şekil 8.a.b.c ve Şekil 9' da görüldüğü gibi Güney-Kuzey yönünde $A-A^{\prime}$ profilleri boyunca kesitler alınmıștır ve aralarındaki uyumu saptayabilmek için bu kesitler çizdirilmiştir (Şekil 14). Karşılaştırma sonucunda en iyi uyumun gravite ters çözüm sonuçlarından kesme dalga boyu $100 \mathrm{~km}$, iterasyon sayısı 1 olan eğri ile referans (Moho) derinliği $28 \mathrm{~km}$ olan $T_{e}=6 \mathrm{~km}$ eğrisi arasında olduğu saptanmıștır (Şekil 14). Bulunan bu sonuç girișim değerlerinin karșılaștırılması ile elde edilen değer ile tutarlılık göstermektedir. Böylelikle, Girit ve çevresini içeren I. Bölge için efektif elastik kalınlık değeri ortalama 6 km'dir. 
DEÜ FMD 22(65), 541-559, 2020

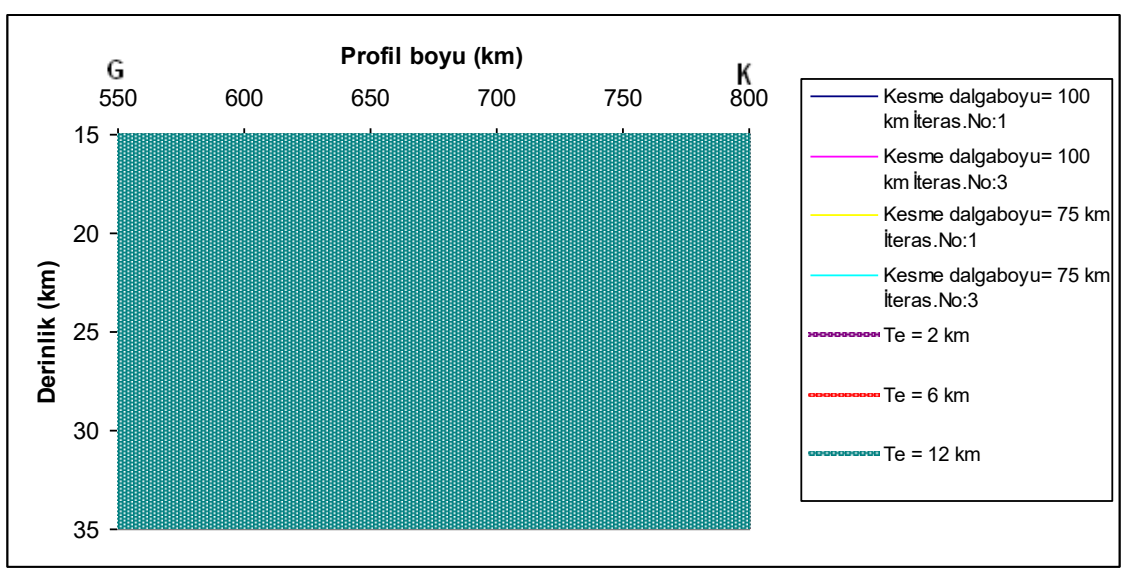

Şekil 14. LithoFLEX 1.2 yazılımı kullanılarak bulunan kabuk-manto arayüzeyi derinlik ve bükülme yüzeyleri verilerinin A-A' profili (Şekil 8, 9)boyunca alınan kesitler.

$28^{\circ}-29.5^{\circ}$ Boylamları ve $33^{\circ}-37^{\circ}$ Enlemleri arasında kalan Rodos baseni ve çevresini içeren II. Bölge olarak adlandırılan bölge için gözlemsel girișim değerlerinin $0.01<k<0.1$ arasındaki dalga sayısı değerleri kullanılmıştır. Güç spektrumu yöntemi sonucunda yapı derinliği 26 km olarak bulunmuş ve ortalama kabuk kalınlığı $T_{c}=26 \mathrm{~km}$ olarak belirlenmiștir. Kuramsal girişim değerleri $T_{e}=0,5,10$ ve $15 \mathrm{~km}$ değerleri için hesaplanmış ve en iyi uyumu veren değerlerin $5 \mathrm{~km}$ ile $10 \mathrm{~km}$ arasında yaklaşı $8 \mathrm{~km}$ olduğu belirlenmiştir. Gravite ters çözüm ve bükülme düz çözümü hesaplamalarından çıkan sonuçları karşılaștırmak için Şekil 12.a.b.c ve
Șekil 13’ de görüldüğü gibi Güney-Kuzey yönünde A-A' profilleri boyunca kesitler alınmıştır ve karşılaştırılmıştır (Şekil 15). Karşılaştırma sonucunda en iyi uyumun gravite ters çözüm sonuçlarından kesme dalga boyu 100 $\mathrm{km}$, iterasyon sayısı 1 olan eğri ile referans derinliği (Moho derinliği) $30 \mathrm{~km}$ olan $\mathrm{T}_{\mathrm{e}}=8 \mathrm{~km}$ eğrisi arasında olduğu saptanmıştır (Şekil 15). Bulunan bu sonuç, girișim değerlerinin karşılaştırılması ile elde edilen değer ile tutarlılık göstermektedir. Sonuç olarak, Rodos baseni ve çevresini içeren II. bölge için efektif elastik kalınlık değeri ortalama 8 km'dir.

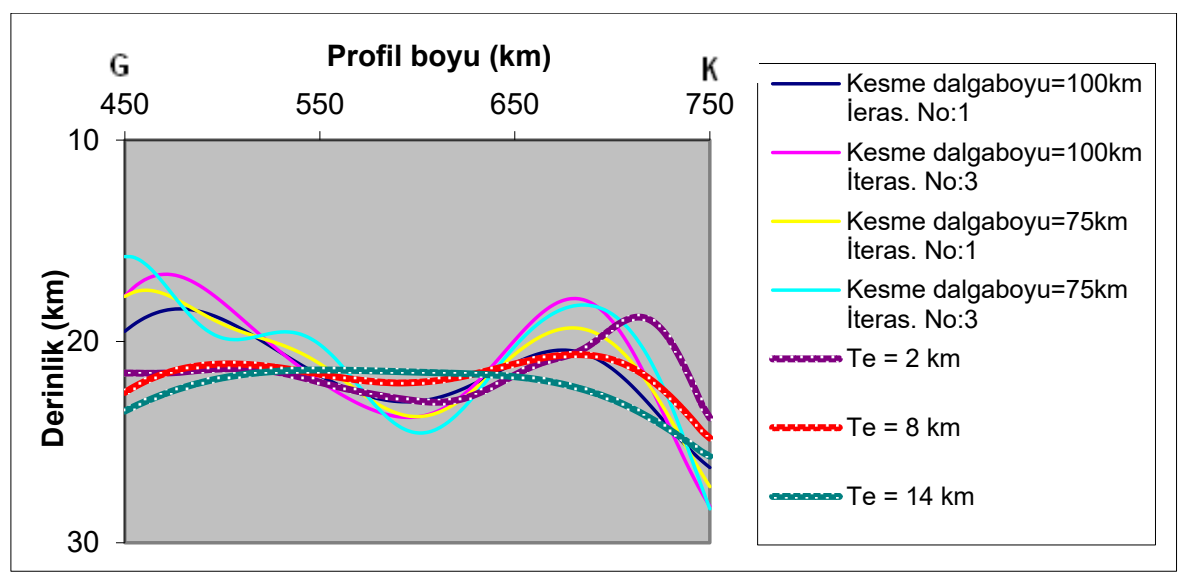

Şekil 15. LithoFLEX 1.2' yazılımı kullanılarak bulunan kabuk-manto arayüzeyi derinlik ve bükülme yüzeyleri verilerinin A-A' profilleri $(S ̧ e k i l 12,13)$ boyunca alınan kesitler. 
Doğu Akdeniz bölgesinde yapılan çalışmalar sonucunda, kabuk-manto ara yüzeylerine ait ortalama bükülme derinliklerinin, en uygun efektif elastik kalınlık değeri ile uyumlu olarak Doğu Akdeniz'de Girit ve çevresinde 19-29 km, Rodos baseni ve çevresinde ise $20-32 \mathrm{~km}$ arasında değiştiği saptanmıştır. Bu sonuçlar, literatürde Girit Adası ve çevresinde yapılmış kabuk çalışmaları [13-15, 58] sonuçları ile uyumludur. Girit çevresine ait gravite ters çözüm ve topoğrafya ile efektif elastik kalınlık kullanılarak düz çözüm yöntemlerinden elde edilen kabuk-manto ara yüzeylerine ait bükülme derinlikleri birbiri ile uyumludur. Doğu Akdeniz'in doğu kesiminde ise topoğrafya yükünden elde edilen ara yüzey bükülmesi gravite ters çözüm değerlerinden elde edilenden daha fazladır. Bunun nedeni litosfer kabuk sınırındaki tektonik, termal problemlerden kaynaklabilir, özellikle bu bölge okyanusal kökenli olduğundan sıvı içeriği fazla olup dayanımı azaltabilir. Dayanımın azalması rijiditenin azalması ve bununla paralel olarak elastik kalınlığın azalması anlamına gelmektedir. Kabuktaki rijiditenin azalması ortamın kırılgan (brittle) durumdan, akışkan (ductile) hale geçmesi ile açıklanabilmektedir. $\mathrm{Bu}$ çalıșma kapsamında sonuç olarak Doğu Akdeniz bölgesi için bu yapılan yaklașımların geçerli olabileceğine işaret edilmektedir.

\section{Teșekkür}

Trieste Üniversitesi'nden Prof. Dr. Carla Braitenberg'e Lithoflex yazılımına erişim ve Erasmus değişim program kapsamında birlikte çalışmamıza olanak sağlamasından dolayı teșekkür ederiz. Ayrıca değerli değerlendirmelerinden dolayı iki hakeme ve editore teşekkürlerimizi sunarız. Bu çalışma, Dokuz Eylül Üniversitesi 2006.KB.FEN.031 nolu Bilimsel Araștırma Projesi tarafından finansal olarak desteklenmiştir.

\section{Kaynakça}

[1] Sengör, A.M.C., Yllmaz, Y. 1981. Tethyan evolution of Turkey: a plate tectonic approach. Tectonophysics, Cilt 75, s. 181-241.

[2] Dewey, J.F., Hempton, M.R., Kidd, W.S.F., Saroğlu, F, Şengör, A.M.C. 1986. Shortening of continental lithosphere: the neotectonics of eastern Anatolia-a young collision zone. In: Coward, M.P., Ries, A.C (Eds.), Collision Tectonics. Geological Society Special Publication, Cilt 19, s. 3 - 36.

[3] Hancock, P.L., Barka, A.A. 1981. Opposed shear senses inferred from neotectonic mesofractures systems in the North Anatolian fault zone. J. Struct. Geol., Cilt 3, s. 383- 392 .
[4] Taymaz, T., Jackson, J., Mckenzie, D.P. 1991. Active tectonics of the North and Central Aegean Sea. Geophysical Journal International, Cilt 106, s. 433-490.

[5] Okay, A.I. 2000. Was the late Triassic orogeny in Turkey caused by collision of an oceanic plateau? In: Bozkurt E., Winchester J.A. and Piper J.D.A (eds) Tectonics and magmatism in Turkey and surrounding area. Geological Society, London Special Publications, Cilt 173, s. 25-41.

[6] Zitter, T.A.C., Woodside, J.M., Mascle, J. 2003. The Anaximander Mountains: a clue to the tectonics of southwest Anatolia. Geological Journal, Cilt 38, s. 375- 394.

[7] Salamon, A., Hofstetter, A., Garfunkel, Z., Hagai, R. 2003. Seismotectonics of the Sinai subplate-eastern Mediterranean region. Geophysical Journal International, Cilt 155, s. 149-173.

[8] Aksu, A.E., Hall, J., Yaltırak, C. 2005. Miocene to Recent tectonic evolution of the eastern Mediterranean: New pieces of the old Mediterranean puzzle. Marine Geology, Cilt 221, s. 1-13.

[9] Papazachos, B.C., Karakostas, V., Papazachos, C., Scordilis, E. 2000. The geometry of the WadatiBenioff zone and lithospheric kinematics in the Hellenic arc. Tecto, Cilt 319, s. 275-300.

[10] Papazachos, C., Nolet, G. 1997. P and S deep velocity structure of the Hellenic area obtained by robust nonlinear inversion of travel times. Journal of Geophysical Research: Solid Earth, Cilt 102(B4), s. 8349-8367.

[11] Gönenç, T., Akgün, M., Ergün, M. 2009. Girit Bölgesinin izafi kabuk kalınlığı değişiminin manyetik ve serbest hava gravite anomalileri ile irdelenmesi. Dokuz Eylül Üniversitesi Mühendislik Fakültesi Fen ve Mühendislik Dergisi, DEÜ FMD Cilt 11(1), s. 44-56.

[12] Hall, J., Aksu, A. E., Yaltırak, C., Winsor, J. D. 2009. Structural architecture of the Rhodes Basin: a deep depocentre that evolved since the Pliocene at the junction of Hellenic and Cyprus Arcs, eastern Mediterranean. Marine Geology, Cilt 258(1-4), s. 123.

[13] Snopek, K., Meier, T., Endrun, B., Bohnhoff, M., Casten, U. 2007. Comparison of gravimetric and seismic constraints on the structure of the Aegean lithosphere in the forearc of the Hellenic subduction zone in the area of Crete. Journal of Geodynamics, Cilt 44, s. 173-185.

[14] Makris, J., Yegorova, T. 2006. A 3-D density-velocity model between the Cretan Sea and Libya. Tectonophysics, Cilt 417(3-4), s. 201-220.

[15] Gönenç, T., Akgün, M. 2012. Structure of the hellenic subduction zone from gravity gradient functions and seismology. Pure and Applied Geophysics, Cilt 169(7), s. 1231-1255.

[16] Watts, A.B. 2001. Isostasy and flexure of the lithosphere, England, Cambridge University Pres. s. 87-283.

[17] Dorman, L.M., Lewis, B.T.R. 1970. Experimental isostasy 1: theory of determination of the Earth's response to a concentrated load. Journal of Geophysical Research, Cilt 75, s. 3357-3365. 


\section{DEÜ FMD 22(65), 541-559, 2020}

[18] McKenzie, D.P. Bowin, C.0. 1976. The relationship between bathymetry and gravity in the Atlantic Ocean. Journal of Geophysical Research, Cilt 81, s. 1903-1915

[19] Zuber, M.T., Bechtel, T.D., Forsyth, D.W. 1989 Effective elastic thicknesses of the lithosphere and mechanisms of isostatic compensation in Australia. Journal of Geophysical Research: Solid Earth, Cilt 94(B7), s. 9353-9367.

[20] Wang, Y., Mareschal, J.C. 1999. Elastic thickness of the lithosphere in the Central Canadian Shield. Geophysical Research Letters, Cilt 26(19), s. 30333036.

[21] Rajesh, R.S., Mishra, D.C. 2004. Lithospheric thickness and mechanical strength of the Indian shield. Earth and Planetary Science Letters, Cilt 225(3-4), s. 319-328.

[22] Pamukçu, O. 2004. Doğu Anadolu Bölgesi'nin jeodinamik yapısının jeofizik verilerle irdelenmesi. Dokuz Eylül Üniversitesi, Fen Bilimleri Enstitüsü, 140s, Doktora Tezi, İzmir.

[23] Yurdakul, A. 2005; Izostatik yanıt fonksiyonları ile litosfer yapılarının irdelenmesi, Dokuz Eylül Üniversitesi Fen Bilimleri Enstitüsü, 104s, Yüksek Lisans tezi, İzmir.

[24] Luis, J.F., Neves, M.C. 2006. The isostatic compensation of the Azores Plateau: A 3D admittance and coherence analysis. Journal of Volcanology and Geothermal Research, Cilt 156(1-2), s. 10-22.

[25] Pamukçu, O.A., Akçı̆̆, Z., Demirbaş, Ş., Zor, E. 2007. Investigation of crustal thickness in Eastern Anatolia using gravity, magnetic and topographic data. Pure and Applied Geophysics, Cilt 164(11), s. 2345-2358.

[26] Pamukcu, O., Yurdakul, A. 2008. Isostatic compensation in western Anatolia with estimate of the effective elastic thickness. Turkish Journal of Earth Sciences, Cilt 17(3), s. 545-557.

[27] Oruç, B., Sönmez, T. 2017. The rheological structure of the lithosphere in the Eastern Marmara region, Turkey. Journal of Asian Earth Sciences, Cilt 139, s. 183-191.

[28] Oruç, B., Pamukçu, O., Sayın, T. 2019. Isostatic Moho undulations and estimated elastic thicknesses of the lithosphere in the central Anatolian plateau, Turkey. Journal of Asian Earth Sciences, Cilt 170, s. 166-173.

[29] Braitenberg, C., Wienecke, S., Wang Y. 2006 Basement structures from satellite-derived gravity field: South China Sea ridge. Journal of Geophysical Research: Solid Earth, 111(B5).

[30] Wienecke, S. 2006. A new analytical solution for the calculation of flexural rigidity: significance and applications. Free University, Doktora Tezi , BerlinGermany.

[31] Gessner, K., Gallardo, L.A., Markwitz, V., Ring, U., Thomson, S.N. 2013. What caused the denudation of the Menderes Massif: Review of crustal evolution, lithosphere structure, and dynamic topography in southwest Turkey. Gondwana research, Cilt 24(1), s. 243-274.

[32] Smith, W.H., Sandwell, D.T. 1997. Global sea floor topography from satellite altimetry and ship depth soundings. Science, Cilt 277(5334), s. 1956-1962.
[33] Turcotte, D.L., Schubert, G. 1982. Geodynamics: Applications of. Continuum Physics to Geological Problems. Wiley, New York, 140.

[34] Timoshenko, S. 1958. Strength of materials. Part I. Elementary theory and problems. New York: D. Van Nostrand Co.

[35] McKenzie, D., Fairhead, D. 1997. Estimates of the effective elastic thickness of the continental lithosphere from Bouguer and free air gravity anomalies. Journal of Geophysical Research, Cilt 102, s. 27523-27552.

[36] Forsyth, D.W. 1985. Subsurface loading and estimates of the flexural rigidity of continental lithosphere. Journal of Geophysical Research: Solid Earth, Cilt 90(B14), s. 12623-12632.

[37] Parker, R.L. 1972. The rapid calculation of potential anomalies. Geophysics Journal Research Astr. Soc., Cilt 31, s. 447-550.

[38] Braitenberg, C., Zadro M. 1999. Iterative 3D gravity inversion with integration of seismologic data. Bollettino Di Geofisica Teorica Ed applicata, Cilt 40, s. 469-476.

[39] Rusya Savunma Bakanlığı Navigasyon ve Oşinografi Daire Bașkanlığı (Department of Navigation and Oceanography of the Ministry of Defence of the Russian Federation) 1989. Bouguer gravite haritası.

[40] Nagy, D. 1966. The gravitational attraction of a right rectangular prism. Geophysics, Cilt 30, s. 362-371.

[41] Bohnhoff, M., Makris, J., Papanikolaou, D., Stavrakakis, G. 2001., Crustal investigation of the Hellenic subduction zone using wide aperture seismic data, Tectonophysics, Cilt 343 (3-4), s. 239262.

[42] Spector, A., Grant, F.S. 1970. Statistical models for interpreting aeromagnetic data. Geophysics, Cilt 35(2), s. 293-302.

[43] Ergün, M., Okay, S., Sarı, C., Oral, E. Z. ,Ash, M., Hall, J., Miller H. 2005. Gravity anomalies of the Cyprus Arc and their tectonic implications. Marine Geology, Cilt 221, s. 349-358.

[44] Le Pichon, X., Angelier, J. 1979. The hellenic arc and trench system: A key neotectonic evoluation of the eatern Mediterranean area, Tectonophysics, Cilt 60, s. $1-42$.

[45] Ryan, W.B., Kastens, K.A., Cita, M.B. 1982. Geological evidence concerning compressional tectonics in the Eastern Mediterranean. Tectonophysics, Cilt 86(13), s. 213-242.

[46] Le Pichon, X., Lybéris, N., Angelier, J., Renard, V. 1982. Strain distribution over the east Mediterranean ridge: A synthesis incorporating new Sea-Beam data. Tectonophysics, Cilt 86(1-3), s.243-274.

[47] Spakman, W., Wortel, M.J.R., Vlaar, N.J. 1988. The Hellenic subduction zone: a tomographic image and its geodynamic implication. Geophyical Research Letters, Cilt 15, s. 60-63.

[48] Truffert, C., Chamot-Rooke, N., Lallemant, S., De Voogd, B., Huchon, P., Pichon, X. 1993. The crust of the Western Mediterranean Ridge from deep seismic data and gravity modelling. Geophyical Journal International, Cilt 114(2), s. 360-372.

[49] Chaumillon, E., Mascle, J., Hoffmann, H.J. 1996. Deformation of the western Mediterranean Ridge: Importance of Messinian evaporitic formations. Tectonophysics, Cilt 263(1-4), s. 163-190. 


\section{DEÜ FMD 22(65), 541-559, 2020}

[50] Chaumillon, E., Mascle, J. 1997. From foreland to forearc domains: new multichannel seismic reflection survey of the Mediterranean Ridge accretionary complex (Eastern Mediterranean). Marine Geology, Cilt 138(3-4), s. 237-259.

[51] Delibasis, N., Ziazia, M., Voulgaris, N., Papadopoulos, T., Stavrakakis, G., Papanastassiou, D., Drakatos, G. 1999. Microseismic activity and seismotectonics of Heraklion area (central Crete Island, Greece). Tectonophysics, Cilt 308(1-2), s. 237-248.

[52] Knapmeyer, M., Harjes, H.P. 2000. Imaging crustal discontinuities and the down going slab beneath western Crete. Geophysical Journal International, Cilt 143(1), s. 1-21.

[53] Stiros, S.C. 2000. TheAD365 Crete earthquake and possible seismic clustering during the fourth to sixth centuries AD in the Eastern Mediterranean: a review of historical and archaeological data. J. Struct. Geol. Cilt 23, s. 545-562.

[54] Huguen, C., Mascle, J., Chaumillon, E., Woodside, J.M., Benkhelil, J., Kopf, A., Volkonskaia, A. 2001. Deformational styles of the Eastern Mediterranean Ridge and surroundings from combined swath mapping and seismic reflection profiling. Tectonophy, Cilt 343, s. 21-47.

[55] Brönner, M. 2003. Untersuchung des Krustenaufbaus entlang des Mediterranen Ruckens abgeleitet aus geophysikalischen Messungen. In: Berichte aus dem Zentrum für Meeres und Klimaforschung, Reihe C, Geophysik Nr. 21. Universitat Hamburg, p. 170.

[56] Li, X., Bock, G., Vafidis, A., Kind, R., Harjes, H., Hanka, W., Wylegalla, K., Van Der Meijde, M., Yuan, X. 2003. Receiver function study of the Hellenic subduction zone: imaging crustal thickness variations and the oceanic Moho of the descending African lithosphere. Geophysical Journal International, Cilt 155, s. 733748.

[57] Zitter, T.A.C., Woodside, J.M., Mascle, J. 2003. The Anaximander Mountains: a clue to the tectonics of southwest Anatolia. Geological Journal, Cilt 38, s. 375-394.

[58] Meier, T., Rische, M., Endruna, B., Vafidis, A., Harjes, H.P. 2004. Seismicity of the Hellenic subduction zone in the area of western and central Crete observed by temporary local seismic networks. Tecto, Cilt 383, s. 149-169.

[59] Brocher, M.T. 2005. Empirical Relations between Elastic Wavespeeds and Density in the Earth's Crust. Bulletin of the Seismological Society of America, Cilt 95(6), s. 2081-2092.

[60] Casten, U., Snopek, K. 2006. Gravity modelling of the Hellenic subduction zone-a regional study. Tectonophysics, Cilt 417(3-4), s. 183-200.

[61] Yolsal-Çevikbilen, S., Taymaz, T. 2012. Earthquake source parameters along the Hellenic subduction zone and numerical simulations of historical tsunamis in the Eastern Mediterranean. Tectonophysics, Cilt 536, s. 61-100.

[62] Özbakır, A. D., Şengör, A. M. C., Wortel, M. J. R., Govers, R. 2013. The Pliny-Strabo trench region: A large shear zone resulting from slab tearing. Earth and Planetary Science Letters, Cilt 375, s. 188-195.

[63] Gallen, S.F., Wegmann, K.W., Bohnenstiehl, D.R., Pazzaglia, F.J., Brandon, M.T., Fassoulas, C. 2014
Active simultaneous uplift and margin-normal extension in a forearc high, Crete, Greece. Earth and Planetary Science Letters, Cilt 398, s. 11-24.

[64] Pamukçu, 0. 2016. Geodynamic assessment of Eastern Mediterranean region: a joint gravity and seismic $b$ value approach. Arabian Journal of Geosciences, Cilt 9(360), s.1-13.

[65] Şahin, Ş., Çiftçi, C., Okyar, M., Öksüm, E. 2018. Doğu Akdeniz'in Kabuk Yapısı ve Sismik Hız Dağlımının Üç Boyutlu Sismik Tomografi ile Belirlenmesi. Süleyman Demirel Üniversitesi Fen Bilimleri Enstitüsü Dergisi, Cilt 22(2), s. 961-971.

[66] Hall, J., Aksu, A. E., Elitez, I., Yaltırak, C., Çifçi, G. 2014. The Fethiye-Burdur Fault Zone: a component of upper plate extension of the subduction transform edge propagator fault linking Hellenic and Cyprus Arcs, Eastern Mediterranean. Tectonophysics, Cilt 635, s. 80-99.

[67] Elitez, İ., Yaltırak, C., Aktuğ, B. 2016. Extensional and compressional regime driven left-lateral shear in southwestern Anatolia (eastern Mediterranean): The Burdur-Fethiye Shear Zone. Tectonophysics, Cilt 688, s. 26-35. 